\title{
PENGARUH OBJEK WISATA DANAU KELIMUTU DAN TENUN IKAT TERHADAP KONDISI EKONOMI MASYARAKAT
}

\author{
${ }^{1}$ Maria Agustina Muda; ${ }^{2}$ Suwito \\ ${ }^{1}$ 2) Universitas Kanjuruhan Malang \\ Email: ${ }^{1)}$ mariaagustinamuda06@gmail.com; ${ }^{2)}$ suwito@unikama.ac.id
}

\begin{abstract}
Abstrak
Danau Kelimutu adalah danau kawah yang terletak di puncak gunung kelimutu tepatnya terletak di Desa Pemo Kabupaten Ende Flores NTT, Indonesia. Salah satu kelebihan dari objek wisata Danau Kelimutu adalah danau kawah dengan memiliki 3 macam warna yaitu merah, biru, dan putih. Objek wisata Danau Kelimutu ini memiliki daya tarik tersendiri yang mampu menarik wisatawan untuk berkunjung yaitu didukung oleh potensi yang lain salah satunya adalah Tenun Ikat. Tujuan penelitian ini adalah Mengetahui pengaruh objek wisata Danau Kelimutu dan Tenun Ikat terhadap kondisi ekonomi masyarakat Desa Pemo Kabupaten Ende. Metode yang digunakan dalam penelitian ini adalah pendekatan kuantitatif dengan variabel bebas yaitu Pengaruh Objek Wisata Danau Kelimutu (X1) dan Tenun Ikat (X2), dan variabel terikatnya adalah Kondisi Ekonomi Masyarakat. Rancangan penelitian ini merupakan analisis regresi linear berganda, untuk mengetahui pengaruh Objek Wisata Danau Kelimutu dan Tenun Ikat terhadap kondisi ekonomi masyarakat. Berdasarkan hasil analisis SPSS 16.0 For Windows terdapat pengaruh yang signifikan antara keberadaan objek wisata Danau Kelimutu (X1) dan Tenun Ikat (X2) terhadap kondisi ekonomi masyarakat (Y). Berdasarkan hasil analisis yang diperoleh menunjukan koefisien regresi yang diperoleh yaitu $\mathrm{Y}=13.360+-0.021 \mathrm{X}_{1}+0.266 \mathrm{X}_{2}$ dengan nilai sebesar $12,5 \%$, dan sisanya $(87,5 \%)$ dijelaskan atau diberikan oleh variabel-variabel lain yang tidak diteliti dalam penelitian ini. Hal ini menunjukan bahwa keberadaan objek wisata Danau Kelimutu tidak berpengaruh terhadap kondisi ekonomi masyarakat dan Tenun Ikat berpengaruh terhadap kondisi ekonomi masyarakat. Saran dalam penelitian ini diharapkan menjadi bahan masukan untuk seluruh masyarakat agar lebih memanfaatkan potensi dan keahliannya terlebih dahulu khusus pada sektor pariwisata.
\end{abstract}

Kata Kunci: Objek wisata, Danau Kelimutu, tenun ikat, kondisi ekonomi masyarakat

\section{PENDAHULUAN}

Kabupaten Ende merupakan salah satu kabupaten di Indonesia yang terletak di propinsi NTT yang memiliki berbagai potensi wisata. Hal tersebut dapat dilihat dari keberadaan objek wisata yang terdapat di kabupaten ini. Salah satu objek wisata yang terdapat di kabupaten Ende adalah Danau Kelimutu yang dikenal dengan Danau Tiga Warna dan objek wisata Tenun Ikat pula yang berada di sekitar wilayah danau Kelimutu. Danau Kelimutu adalah danau kawah yang terletak di puncak gunung kelimutu (gunung api) yang terletak di pulau Flores Propinsi NTT, Indonesia. Lokasi gunung ini tepatnya di Desa Pemo Kecamatan Kelimutu Kabupaten Ende.

Salah satu kelebihan dari objek wisata Danau Kelimutu adalah danau kawah dengan memiliki 3 macam warna yang berbeda satu dengan yang lain ada merah, biru, dan putih. Objek wisata Danau Kelimutu ini memiliki daya tarik tersendiri yang mampu menarik wisatawan untuk berkunjung. Hal tersebut dikarenakan objek wisata tersebut tidak hanya menyajikan potensi berupa danau kelimutu saja tetapi juga didukung oleh potensi yang 
lain salah satunya adalah Tenun Ikat. Kain tenun ikat banyak ditawarkan dan menjadi salah satu produk khas lokal dan dijual oleh penduduk setempat kepada para wisatawan yang berkunjung ke tempat wisata Danau Kelimutu. Sehingga dengan banyaknya wisatawan yang berkunjung berpeluang besar bagi penjual untuk medapat keuntungan dari hasil jualannya. Maka pendapatan ekonomi masyarakat semakin meningkat dengan banyaknya wisatawan yang berkunjung ketempat penjualan kain tenun ikat, dan sebaliknya jika wisatawan sedikit berkunjung ke tempat penjualan Tenun Ikat maka pendapatan masyarakatpun berkurang.

Berdasarkan latar belakang masalah tersebut diatas dapat merumuskan masalah penelitian sebagai berikut : (1) Apakah ada Pengaruh objek wisata Danau Kelimutu terhadap kondisi ekonomi masyarakat Desa Pemo Kabupaten Ende (2) Apakah ada pengaruh objek wisata Tenun Ikat terhadap kondisi ekonomi masyarakat Desa Pemo Kabupaten Ende (3) Apakah ada Pengaruh objek wisata Danau Kelimutu dan Tenun Ikat terhadap kondisi ekonomi masyarakat Desa Pemo Kabupaten Ende.

Penelitiam ini bertujan untuk: (1) Mengetahui Pengaruh objek wisata Danau Kelimutu terhadap kondisi ekonomi masyarakat Desa Pemo Kabupaten Ende; (2) Mengetahui pengaruh objek wisata Tenun Ikat terhadap kondisi ekonomi masyarakat Desa Pemo Kabupaten Ende; (3) Mengetahui pengaruh objek wisata Danau Kelimutu dan Tenun Ikat terhadap kondisi ekonomi masyarakat Desa Pemo Kabupaten Ende

\section{METODE PENELITIAN}

Penelitian ini menggunakan pendekatan kuantitatif. Teknik pengumpulan data dalam penelitian ini dilakukan dengan menggunakan cara, yaitu:

a) Wawancara dengan reponden yaitu masyarakat yang berada di Desa Pemo Kecamatan Kelimutu Kabupaten Ende NTT.

b) Observasi dengan survei ketempat penelitian yaitu di desa Pemo Kecamatan Kabupaten Ende.

c) Kuisioner/Angket yang ditujukan kepada masyarakat desa Pemo Kecamatan Kabupaten Ende.

d) Dokumentasidigunakan untuk mencari mengenai hal-hal atau variabel yang berupa catatan, foto, transkip, buku ilmu budaya dasar, surat kabar, majalah, notulen rapat, dan sebagainya.

Analisis data yaitu analisis deskriptif dan analisis regresi linear berganda dengan program software statistik SPSS 16.0 for Windows.

\section{HASIL DAN PEMBAHASAN}

\section{Uji Validitas dan Reliabilitas}

a.Uji Validitas

Uji validitas angket dilakukan melalui teknik Corrected Item-Total Correlation menggunakan SPSS 16.0 for Windows. Hasil uji validitas adalah perbandingan $r_{\text {hitung }}$ dengan $r_{\text {tabel }}$ pada signifikansi $5 \%$. Jika nilai $r_{\text {hitung }} \geq r_{\text {tabel }}$, maka item valid. Berdasarkan hasil uji validitas, diketahui hasil uji validitas seluruh item angket variabel objek wisata Danau Kelimutu $\left(\mathrm{X}_{1}\right)$, objek wisata tenun ikat $\left(\mathrm{X}_{2}\right)$, dan kondisi ekonomi masyarakat $(\mathrm{Y})$ adalah valid (sah), sedangkan item-item angket yang gugur (tidak valid) tidak ada. 
b.Uji Reliabilitas

Uji reliabilitas angket dilakukan melalui SPSS 16.0 for Windows. Pengujian reliabilitas dilakukan dengan memperlihatkan varian setiap skor item dan skor total yang dihitung berdasarkan metode Cronbach Alpha $(\alpha)$. Cara pengambilan keputusan reliabilitasnya menggunakan batasan 0,6 , dengan kriteria, yaitu reliabilitas < 0,6 berarti rendah, reliabilitas 0,7 berarti cukup, dan reliabilitas > 0,8 berarti Tinggi. Berdasarkan hasil uji reliabilitas, diketahui nilai Cronbach's Alpha angket variabel objek wisata Danau Kelimutu $\left(\mathrm{X}_{1}\right)$ yaitu 0,866 dengan status reliabilitas „Tinggiee, nilai Cronbach's Alpha angket objek wisata tenun ikat $\left(\mathrm{X}_{2}\right)$ yaitu 0,902 dengan status reliabilitas „Tinggiee, serta Cronbach's Alpha angket variabel kondisi ekonomi masyarakat (Y) yaitu 0,781 dengan status reliabilitas "Cukup". Dengan demikian, maka dapat disimpulkan bahwa instrumen angket ketiga variabel dalam penelitian ini memiliki status reliabilitas yang baik atau dapat diterima.

\section{$2 \quad$ Uji Hipotesis}

Data-data penelitian ini dianalisis menggunakan analisis regresi linier berganda (multiple regressions). Rangkuman hasil analisis regresi linier berganda (multiple regressions) dapat dilihat dalam tabel berikut ini.

\begin{tabular}{|c|c|c|c|}
\hline \multicolumn{4}{|l|}{ Regressions } \\
\hline Model & $\begin{array}{r}\text { Koefisiena } \\
\text { Regresi }\end{array}$ & $\mathrm{t}$ & Sig. \\
\hline (Constant) & 13.360 & 3.027 & 0.004 \\
\hline $\mathrm{X}_{1}$ & -.021 & -.247 & 0.806 \\
\hline$X_{2}$ & 0.266 & 2.358 & 0.023 \\
\hline
\end{tabular}

Berdasarkan hasil analisis regresi linier berganda di atas, maka dapat disusun persamaan regresinya, sebagai berikut:

$$
Y=13.360+-0.021 X_{1}+0.266 X_{2}
$$

Berdasarkan persamaan regeresi di atas, maka dapat diuraikan hal-hal, sebagai berikut:

a. Nilai koefisien $a$ (constant) sebesar 13.360. Hal ini berarti bahwa jika variabel- variabel bebas $\left(\mathrm{X}_{1}\right.$ dan $\left.\mathrm{X}_{2}\right)$ nilainya sama dengan nol maka diperkirakan kondisi ekonomi masyarakat mengalami kenaikan sebesar 13.360

Nilai koefisien $b_{1}$ sebesar -0.021 , yang menunjukkan tidak adanya pengaruh yang searah objek wisata Danau Kelimutu terhadap kondisi ekonomi masyarakat Desa Pemo Kecamatan Kelimutu Kabupaten Ende NTT. Hal ini berarti bahwa ketika kualitas objek wisata Danau Kelimutu $\left(\mathrm{X}_{1}\right)$ tidak meningkat maka tidak diikuti oleh peningkatan kondisi ekonomi masyarakat

(Y) sebesar -0.021. Dengan demikian, maka keunikan warna air Danau Kelimutu, Daerah Taman Nasional Kelimutu yang bergelombang mulai ringan sampai berat dengan relief berbukit-bukit sampai bergununggunung, kondisi lingkungan alam di sekitar Danau Kelimutu yang terjaga dengan baik, serta lokasi objek wiasata Danau Kelimutu yang dekat dengan tempat tinggal masyarakat setempat merupakan indikator dari variabel bebas objek wisata Danau Kelimutu tidak berpengaruh positif terhadap kondisi ekonomi masyarakat Desa Pemo Kecamatan Kelimutu Kabupaten Ende NTT.

b. Nilai koefisien $b_{2}$ sebesar 0,266, yang menunjukkan adanya pengaruh yang searah objek wisata tenun ikat terhadap kondisi ekonomi masyarakat Desa Pemo Kecamatan Kelimutu Kabupaten Ende NTT. Hal ini berarti bahwa ketika kualitas objek wisata 
tenun ikat $\left(\mathrm{X}_{2}\right)$ meningkat maka akan diikuti oleh peningkatan kondisi ekonomi masyarakat (Y) sebesar 0.266 Dengan demikian, maka ciri khas yang terdapat pada tenun ikat, keragaman hias/ motif yang unik pada tenun ikat, serta keindahan tenun ikat dan nilai jual yang tinggi dari tenun ikat merupakan indikator dari variabel bebas objek wisata tenun ikat yang berpengaruh positif terhadap kondisi ekonomi masyarakat Desa Pemo Kecamatan Kelimutu Kabupaten Ende NTT.

Dalam analisis regresi terdapat pula koefisien determinasi $\left(\mathrm{R}^{2}\right)$ yang digunakan sebagai ukuran untuk menyatakan kecocokan garis regresi yang diperoleh. Semakin besar nilai $\mathrm{R}^{2}$ ( $R$ Square) maka semakin kuat pula kemampuan model regresi yang diperoleh untuk menerangkan kondisi yang sebenarnya. Syarat dari koefisien determinasi $\left(\mathrm{R}^{2}\right)$ merupakan besaran non negative, nilainya $0<\mathrm{R}^{2}>1$. Apabila $\mathrm{R}^{2}$ sama dengan 1 maka fungsi regresi $100 \%$ menjelaskan variasi dari nilai

Y. Sebaliknya, jika nilainya 0 maka model yang digunakan sama sekali tidak mendekati nilai Y. Kecocokan model dikatakan baik jika nilai $\mathrm{R}^{2}$ mendekati 1.

Berdasrakan hasil uji koefisien determinasi menggunakan software statistik SPSS 16.0 for Windows maka diketahui nilai $\mathrm{R}^{2}$ ( $R$ Square) sebesar 0,125 . Hal ini menunjukkan bahwa kondisi ekonomi masyarakat Desa Pemo Kecamatan Kelimutu Kabupaten Ende NTT dapat dijelaskan oleh pengaruh objek wisata Danau Kelimutu dan tenun ikat dengan nilai sebesar 12,5\%. Dengan kata lain, variabel objek wisata Danau Kelimutu dan tenun ikat bukanlah faktor-faktor yang memberi kontribusi dominan terhadap kondisi ekonomi masyarakat, karena kontribusinya hanya sebesar $12,5 \%$, sedangkan kontribusi lainnya $(87,5 \%)$ dijelaskan atau diberikan oleh variabelvariabel lain yang tidak diteliti dalam penelitian ini.

Pengujian hipotesis dalam penelitian ini dilakukan dengan cara melihat nilai probabilitas (probability value). Jika nilai probabilitas $(p$ value $)<0,05$, maka hipotesis yang diajukan diterima, namun jika nilai probabilitas ( $p$ value) $>0,05$ maka hipotesis yang diajukan ditolak.

a Pengaruh Objek Wisata Danau Kelimutu Terhadap Kondisi Ekonomi

$\mathrm{H}_{1}$ : Tidak ada pengaruh objek wisata Danau Kelimutu terhadap kondisi ekonomi masyarakat Desa Pemo Kecamatan Kelimutu Kabupaten Ende NTT

Untuk menguji hipotesis $\left(\mathrm{H}_{1}\right)$ di atas secara statistik maka dalam penelitian ini dilakukan uji-t dengan melihat nilai probabilitasnya ( $p$ value). Berdasarkan data yang tercantum dalam Tabel 5.8, diketahui variabel bebas objek wisata Danau Kelimutu $\left(\mathrm{X}_{1}\right)$ memiliki nilai $\mathrm{t}_{\text {hitung }}-0.247$ (probabilitas $0.806>$ 0,05). Hal tersebut menunjukkan bahwa $\mathrm{H}_{1}$ ditolak , yang berarti tidak ada pengaruh yang positif dan signifikan objek wisata Danau Kelimutu terhadap kondisi ekonomi masyarakat Desa Pemo Kecamatan Kelimutu Kabupaten Ende NTT.

b. Pengaruh Objek Wisata Tenun Ikat Terhadap Kondisi Ekonomi

$\mathrm{H}_{2}$ : Ada pengaruh objek wisata tenun ikat terhadap kondisi ekonomi masyarakat Desa Pemo Kecamatan Kelimutu Kabupaten Ende NTT Untuk menguji hipotesis $\left(\mathrm{H}_{2}\right)$ di atas secara statistik maka dalam penelitian ini dilakukan uji-t dengan melihat nilai probabilitasnya ( $p$ value). Berdasarkan 
data yang tercantum dalam Tabel 5.8, diketahui variabel bebas objek wisata tenun ikat $\left(\mathrm{X}_{2}\right)$ memiliki nilai $\mathrm{t}_{\text {hitung }}$ 2.358 (probabilitas $0.023<0,05$ ). Hal tersebut menunjukkan bahwa $\mathrm{H}_{2}$ diterima, yang berarti ada pengaruh yang positif dan signifikan objek wisata tenun ikat terhadap kondisi ekonomi masyarakat Desa Pemo Kecamatan Kelimutu Kabupaten Ende NTT.

c. Pengaruh Objek Wisata Danau Kelimutu dan Tenun Ikat Terhadap Kondisi Ekonomi

$\mathrm{H}_{3}$ : Ada pengaruh objek wisata Danau Kelimutu dan tenun ikat terhadap kondisi ekonomi masyarakat Desa Pemo Kecamatan Kelimutu Kabupaten Ende NTT.

Untuk menguji hipotesis $\left(\mathrm{H}_{3}\right)$ di atas secara statistik maka dalam penelitian ini dilakukan uji $F$ (uji Anova) dengan melihat nilai probabilitasnya ( $p$ value). Berdasarkan hasil uji Anova seperti yang tercantum di Lampiran 5, diketahui nilai $F_{\text {hitung }} 3.352$ (probabilitas $0,044<0,05)$. Hal tersebut menunjukkan bahwa $\mathrm{H}_{3}$ diterima,yang berarti ada pengaruh yang positif dan signifikan objek wisata Danau Kelimutu dan tenun ikat terhadap kondisi ekonomi masyarakat DesaPemo Kecamatan Kelimutu Kabupaten Ende NTT.

\section{Pengaruh Objek Wisata Danau Kelimutu Terhadap Kondisi Ekonomi Masyarakat Desa Pemo Kabupaten Ende}

Kabupaten Ende merupakan salah satu kabupaten di Indonesia yang terletak di propinsi NTT yang memiliki berbagai potensi wisata. Salah satu objek wisata yang sangat terkenal adalah Danau Kelimutu, bahkan popularitas objek wisata tersebut hingga ke manca negara.

Danau ini dikenal dengan nama Danau Tiga Warna, karena memiliki tiga warna yang berbeda yaitu merah, biru, dan putih. Danau Kelimutu ini tepatnya terletak di Desa Pemo Kecamatan Kelimutu Kabupaten Ende NTT. Keunikan tersebut menyebabkan danau ini begitu populer dan sering dikunjungi oleh wisatawan domestik maupun manca negara. Selain keunikan warna danaunya, objek wisata Danau Kelimutu juga didukung oleh potensi yang lain seperti Mata Air Ae Ata Fai Ata Kaki, Sa ${ }^{e e}$ Ria/Rumah Adat, Nggua Joka Ju (pesta adat setiap bulan oktober), agrowisata, pemandian air panas, keindahan air terjun, bumi perkemahan, serta pemandangan yang indah dan udara pegunungan yang sejuk.

Realita tersebut menimbulkan dampak bagi masyarakat yang tinggal di sekitarnya, khususnya di Desa Pemo Kecamatan Kelimutu Kabupaten Ende NTT. Salah satu dampaknya adalah perekonomian masyarakat setempat menjadi semakin maju, oleh karena adanya objek wisata yang ada di sekitar wilayah tempat tinggalnya. Hal ini sejalan dengan pendapat Billah (2011) yang menyatakan "adanya objek wisata daerah memberi peluang bagi setiap individu yang tinggal di daerah tersebut untuk membuka berbagai usaha guna mengangkat perekonomiannya”.

Hal tersebut sesuai dengan hasil analisis data penelitian ini menunjukkan bahwa variabel bebas objek wisata Danau Kelimutu $\left(\mathrm{X}_{1}\right)$ memiliki nilai thitung -0.247 (probabilitas0.806<0,05). Hal tersebut menunjukkan bahwa $\mathrm{H}_{1}$ ditolak , yang berarti tidak ada pengaruh yang positif dan signifikan objek wisata Danau 
Kelimutu terhadap kondisi ekonomi masyarakat Desa Pemo Kecamatan Kelimutu Kabupaten Ende NTT.

Uraian di atas menjelaskan bahwa objek wisata Danau Kelimutu tidak menjadi salah satu faktor penentu perkembangan ekonomi masyarakat Desa Pemo Kecamatan Kelimutu Kabupaten Ende NTT. Berdasarkan uraian di atas, maka dapat disimpulkan tidak ada pengaruh yang positif dan signifikan objek wisata Danau Kelimutu terhadap kondisi ekonomi masyarakat Desa Pemo Kecamatan Kelimutu Kabupaten Ende NTT.

\section{Pengaruh Objek Wisata Tenun Ikat Terhadap Kondisi Ekonomi Desa Pemo Kabupaten Ende}

Objek wisata lain yang juga sangat populer di Kabupaten Ende adalah wisata tenun ikat. Kerajinan tenun ikat merupakan salah satu kerajinan tertua di Ende. Kerajinan tenun ikat dimulai setelah zaman neolithikum, yaitu saat masyarakat Ende-Lio mulai menetap di suatu daerah secara berkelompok. Seiring munculnya kebudayaan, maka dimulailah pula kegiatan pembuatan kerajinan tenun ikat. Pembuatan tenun ikat ini memiliki banyak keunikan, karena masih lekat dengan adat istiadat masyarakat Ende-Lio, yang juga lekat dengan hal-hal yang berbau mistis dan gaib. Selain itu, kerjinan tenun ikat yang dibuat oleh wanita-wanita penenun di Desa Pemo masih menggunakan bahan organik, baik untuk bahan pembuatan benang maupun untuk bahan pewarnaan, sehingga warna yang dihasilkan sangat alami dan memiliki keindahan yang berbeda dengan warna yang dihasilkan oleh pewarna kimia.

Proses pembuatannya pun dibuat dengan tangan, tanpa bantuan mesin apapun, adapun alat-alat yang digunakan dalam proses pembuatan kerajinan tenun ikat adalah alat-alat tradisional tanpa bantuan tenaga listrik. Tenun ikat lio memiliki keunikan tersendiri yaitu dimana terbuat dari bahan alami, memiliki beragam warna dan motif yang cantik, memiliki berbagai bentuk kain seperti kain panjang, selendang, dan sal yang tidak kalah dengan daerah lain, warnahnya juga tidak mudah luntur, merupakan bagian dari kebudayaan, dapat disimpan dalam kurun waktu yang sangat lama. Hal ini menjadikan kerajinan tenun ikat semakin unik, karena tidak ada kain yang benar-benar sama dengan kain yang lain, karena prosesnya dikerjakan secara manual tanpa menggunakan mesin.

Oleh karena kekhasan dan keunikan tenun ikat Ende, maka banyak para wisatawan domestik dan manca negara yang mengujungi objek wisata tersebut dan membeli berbagai motif atau ragam tenun ikat yang dihasilkan oleh warga Desa Pemo. Dengan banyaknya wisatawan yang berkunjung berpeluang besar bagi penjual untuk medapat kentungan dari hasil jualannya maka pendapatan ekonomi masyarakat semakin meningkat. Menurut Budiyono (2008), keunikan proses pembuatan dan ragam hias tenun ikat menyebabkan banyak wisatawan yang meminatinya sehingga masyarakat setempat memperoleh pendapatan untuk mencukupi kebutuhan ekonominya.

Hal tersebut sesuai dengan hasil analisis data penelitian ini menunjukkan bahwa variabel bebas objek wisata tenun ikat $\left(\mathrm{X}_{2}\right)$ memiliki nilai $\mathrm{t}_{\text {hitung }} 2.358$ (probabilitas $0.023<$ 0,05). Hal tersebut menunjukkan bahwa $\mathrm{H}_{2}$ diterima, yang berarti ada pengaruh yang positif dan signifikan 
objek wisata tenun ikat terhadap kondisi ekonomi masyarakat Desa Pemo Kecamatan Kelimutu Kabupaten Ende NTT. Hal tersebut sejalan dengan hasil penelitian terdahulu yang pernah dilakukan oleh Ichsan (2015) yang menunjukkan bahwa adanya potensi kerajinan tenun ikat tersendiri sebagai daya tarik wisata di Kabupaten Ende dapat mengangkat perekonomian masyarakat setempat.

Uraian di atas menjelaskan bahwa objek wisata tenun ikat juga menjadi faktor penentu perkembangan ekonomi masyarakat Desa Pemo Kecamatan Kelimutu Kabupaten Ende NTT. Berdasarkan uraian di atas, maka dapat disimpulkan ada pengaruh yang positif dan signifikan objek wisata tenun ikat terhadap kondisi ekonomi masyarakat Desa Pemo Kecamatan Kelimutu Kabupaten Ende NTT.

Berdasarkan pembahasan diatas maka temuan dalam penelitian ini adalah

1. Tidak ada pengaruh yang signifikan objek wisata Danau Kelimutu terhadap kondisi ekonomi masyarakat Desa Pemo Kecamatan Kelimutu Kabupaten Ende NTT.

2. Ada pengaruh yang signifikan objek wisata tenun ikat terhadap kondisi ekonomi masyarakat Desa Pemo Kecamatan Kelimutu Kabupaten Ende NTT.

Tidak Ada pengaruh yang signifikan objek wisata Danau Kelimutu terhadap kondisi ekonomi masyarakat Desa Pemo Kabupaten Ende dan ada pengaruh yang signifikan objek tenun ikat terhadap kondisi ekonomi masyarakat Desa Pemo Kabupaten Ende.

\section{KESIMPULAN DAN SARAN}

\section{Kesimpulan}

Kesimpulan dalam penelitian ini yaitu:

1. Tidak ada pengaruh yang signifikan objek wisata Danau Kelimutu terhadap kondisi ekonomi masyarakat Desa Pemo Kabupaten Ende.

2. Ada pengaruh yang signifikan objek wisata tenun ikat terhadap kondisi ekonomi masyarakat Desa Pemo Kabupaten Ende.

Tidak Ada pengaruh yang signifikan objek wisata Danau Kelimutu terhadap kondisi ekonomi masyarakat Desa Pemo Kabupaten Ende dan ada pengaruh yang signifikan objek tenun ikat terhadap kondisi ekonomi masyarakat Desa Pemo Kabupaten Ende.

\section{Saran}

Saran-saran yang dapat dikemukakan dalam penelitian ini yaitu:

1. Bagi masyarakat

a. Masyarakat setempat yang melakukan usaha di kawasan objek wisata Danau Kelimutu dan tenun ikat harus menjunjung tinggi gotong royong dan persaingan yang sehat sehingga tidak sampai timbul kericuhan di antara sesama pelaku usaha.

b. Harus mengupayakan untuk menjaga kebersihan dan ketertiban di sekitar lokasi objek wisata Danau Kelimutu dan tenun ikat agar para wisatawan yang berkunjung merasa nyaman di sana.

2. Bagi Dinas Pariwisata Kabupaten Ende

a. Harus terus berupaya meningkatkan jumlah wisatawan dengan cara melakukan berbagai promosi wisata. Semakin banyaknya 
wisatawan yang datang akan membantu meningkatan pendapatan masyarakat setempat dari hasil usaha di sekitar Danau Kelimutu maupun hasil kerajinan tenun ikatnya. Dengan demikian, maka pemerintah turut serta dalam memperbaiki kondisi ekonomi masyarakat setempat.

b. Harus selalu melakukan pengawasan terhadap objek wisata Danau Kelimutu dan tenun ikat, terutama berkaitan dengan kebersihan lingkungan dan proses pencampuran budaya lokal dengan pendatang sehingga lingkungan dan kearifan budaya lokal bisa tetap terjaga kelestariannya.

3. Bagi peneliti selanjutnya

a. Dapat menggunakan hasil penelitian ini sebagai bahan rujukan atau sumber kajian teori bagi peneliti selanjutnya yang hendak meneliti konsep judul yang sama dengan penelitian ini.

b. Dapat menambahkan variabelvariabel lain yang tidak diteliti dalam penelitian ini yang berkaitan dengan kondisi ekonomi masyarakat di Kabupaten Ende, misalnya menganalisis kondisi ekonomi masyarakat ditinjau dari asimilasi dan akulturasi budaya, atau kondisi lingkungan sehingga dapat diketahui pengaruh di antara variabel-variabel tersebut.

\section{DAFTAR RUJUKAN}

Alifudin, 2015. Pengaruh Obyek Wisata Alam Danau Kelimutu terhadap Kondisi Ekonomi Masyarakat Desa Koanara Kecamatan Kelimutu Kabupaten Ende-NTT. Skripsi S1,Universitas Kanjuruhan Malang.

Budiyono, dkk. 2008. Kriya Tekstil Untuk SMK Jilid 3. Jakarta: Direktorat pembinaan Sekolah Menengah Kejuruan, Direktorat jenderal Manajemen Pendidikan Dasar dan Menengah Pendidikan Nasional.

Arikunto, S. 2006. Prosedur Penelitian Suatu Pendekatan Praktik. Ed Revisi VI. Penerbit PT Rineka Cipta: Jakarta.

Khoirul. 2010. Hubungan Antara Tingkat dan Jenis Pekerjaan Dengan Partisipasi Masyarakat dalam Pembangunan di Desa Jeetis Kecamatan Jaten Kabupaten Karanganyar Tahun 2009/2010. Surakarta.

Sugiyono. 2011. Metode Penelitian Kuantitatif, Kualitatif dan $R \& D$. Bandung: Afabeta. 